\title{
Research on Wealth Effect of Asset Reorganization in Tourism Industry: Case Study Based on Holistic Listing of Overseas Chinese Town Group
}

\author{
Tingli Liu, Songling Yang, Wei Zhang
}

Economic and Management School, Beijing University of Technology, Beijing, China.

Email: liutingli@bjut.edu.cn

Received August $5^{\text {th }}, 2012$; revised September $6^{\text {th }}, 2012$; accepted September $18^{\text {th }}, 2012$

\begin{abstract}
This study extends previous research by examining how holistic listing affects the short-term and long-term wealth for listed company in China. Case study, event study and financial ratios analysis methods are used in the paper. We measure short-term wealth effect by the extra returns and measure long-term wealth by the five value creation indexes. The results show that holistic listing of group enterprise injects new motivation for value creation and helps shareholders to share both long-term and short-term wealth effects. Our research has implications for group enterprises that are striving to enhance corporate value through capital operation.
\end{abstract}

Keywords: Holistic Listing; Wealth Effects; Value

\section{Introduction}

The twelfth five-year plan for national economy and social development of the People's Republic of China clearly stated that we should take the promoting service industry development as the strategic emphasis of industry upgrading. According to The state council opinions on speeding up the development of tourism published on December 2009, tourism was promoted to national strategy in China and clearly put forward to cultivating a group of competitive large tourism enterprise group. Future more, the twelfth five-year plan for national tourism development of People's Republic of China indicated that the basic direction of development of tourism in China is to cultivating large tourism enterprise group with clear primary business, developing route and competitive advantages. We can safely infer that the tourism group will play a pivotal role in the process of constructing strong tourism country. The possibility of the Chinese tourism enterprise groups grasp the opportunity to develop tourism national brand and realize rapid development depends on their sustainable value creation ability.

Overseas Chinese Town (OCT) group is a large-scale state-owned enterprise in China. The major business of OCT is tourism, OCT already has received 150 million tourists by the end of year 2009 which made OCT is the first brand of tourism industry in China. OCT exclusively launched the Shenzhen OCT holding co. and listed on
Shenzhen securities market in 1997 (stock referred to OCT A). As the listed subsidiary, OCT A provides a platform for capital operation of OCT group. The main business of OCT group implemented holistic listing on capital market in December 2009, which made OCT group has better value creation dynamic mechanism and more clear appeal for value growth. OCT group took the lead in whole group listing in tourism industry in China, so the asset reconstruction mode and the economic effects of whole listing has reference and demonstration effects to other large-scale tourism groups.

This paper analyzes the wealth effect of tourism asset reconstruction and discusses the realization route for value promotion with case study method based on both capital market and financial data. Our results contribute to the capital operation and value enhancement of tourism enterprises in China.

The study is organized a follows. Section 2 reviews the related literatures and theory. Section 3 describes the holistic listing model of OCT. We analyzes the shortwealth effect and long-term wealth effect of OCT respectively in Section 4 and Section 5. Section 6 concludes.

\section{Theory Basis for Holistic Listing and Value Creation}

Different from the western developed countries, Chinese capital market began at the transition period. In order to fulfill the listing requirements, state-owned enterprises 
usually adopted spin-off method and listed the partial sound assets on capital market. The function of capital market has continuously improved with the implementation of the reform of non-tradable, making the interests of major shareholders and small-medium shareholder convergence. Under this background, more and more listed companies intend to increase the scale and competitive ability of business by the holistic listing.

Holistic listing refers to the whole business of stateowned enterprise were reconstructed as a joint stock company and publicly offering stocks, meanwhile, withdraw the original enterprise [1]. The document of The Stateowned Assets Supervision and Administration Commission on promoting the capital adjustment and restructuringof state-owned enterprise clearly pointed out supporting enterprises with sound assets and major business to achieve whole group listing on capital market, encouraging the listed state-owned companies to absorb the whole main business by means of increasing endowment spread and acquiring assets. After the reform of non-tradable shares, the theme of M\&A in Chinese capital market is major shareholders' assets injection into listed company and even whole group listing of parent company [2]. The special phenomenon attracted the attention of scholars, for example, Guan analyzed the advantages and disadvantages of whole group listing [3], Zhang explored the realization route of whole group listing based on boundary theory, internal capital market theory and the financial management goal [4], Ou Yang \& Tang made empirical research on forty companies that finished whole group listing and found the whole group listing contributed to the performance promote and stock raise [5]. However, Zhu et al. found that additional stock issue for major shareholder may be the tunneling channel based on case study [6].

Modern enterprise has different sections with different investment opportunities, in order to maximize the total interest, the headquarter need one visible hand to allocate resources such as labor, technology and capital to improve the investment effectiveness. For group enterprise, much money effect and spare money effect are two paths can be used to increase corporate value, the former refers to the subsidiary of group enterprise can acquire more external capital than as a independent enterprise; the latter refers to group enterprise can allocate the limited capital in different projects. Whole group listing help the internal capital market realize the two functions, which enable group enterprise to own bigger financing platform, to enhance the capital effective and to avoid expropriation of listed company by major shareholder, thus benefit the long run development of group enterprise.

Holistic listing also benefits to promote corporate value from the scale-effect and synergistic-effect. The internal scale economy lies in adjustment and supplement of assets through whole group listing; the external scale economy lies in overall strength enhancement, consolidating market shares of enterprise, providing comprehensive professional service and thus satisfied different market needs [5]. From the viewpoint of diversification strategy, holistic listing contributes to adjustment of assets and decrease diversity operation risk. From the viewpoint of vertical integration strategy, whole group listing benefits to integrate the value chain companies into one trade platform, by which reduces transaction costs.

Based on principal agent relation, private offering helps to increase the equity of major shareholders and unify the interests of major shareholders and corporation, which benefits to alleviate the agent problem and increase corporate value [7]. Myers and Majluf pointed out that private offering may be viewed as a signal that managers believed the market value higher than the intrinsic value due to managers have more information about the company, so the rational investors may reduce the evaluation of corporate value when private offering announcement published, thus induce the negative market reflection [8]. Zhang insisted that the market reflection to whole group listing via private offering to major shareholder was better than other mode of private offerings because the controlling shareholder have motivation to invest sound assets and project to listed companies [9]. According to the information hypothesis, the more possibility of underestimation of current assets value or investment opportunities, the more information effect, thus the market reflection will be stronger $[8,10]$.

\section{The Holistic Listing Mode of OCT Group}

OCT A issued stock publicly in Shenzhen stock exchange at 10 September 1997 . OCT group successfully invested the owned shares of Shenzhen WINDOW of the WORLD, Shenzhen SPLENDID CHINA Co., Shenzhen HAPPY VALLEY Co. and Changsha WINDOW of the WORLD into OCT A after OCT A listed on stock market. OCT A became a holding company specialize in the theme park as the core of the tourism industry and its relevant industry operation. OCT group invested the $40 \%$ shares of HUA FANG Co., one sub-company professional engaged in the real estate business, into the OCT A respectively in 2000 and 2001, from then on, OCT A gradually formed the comprehensive advantage of combination of tourism and real estate businesses. The income of OCT A was relatively single and tourism was the main source of income before 2006, the sales income of real estate and hotel gradually increased after 2006 . Now, OCT A has been preliminary formed the "tourism plus real estate" operation mode and become the major economic growth point of OCT group. The essence of 
the mode lies in to improve the environment and promote the land price based on theme park; rapid recovery of real estate in turn helps to provide development capital for theme tourism business.

OCT group was the sole non-tradable shareholder of OCT A before the reform of non-tradable shares. In 2006, major shareholder of OCT A came up with the scheme of "every 10 shares send 2.8 shares", thereby, realized the full circulation of OCT A shares. Whole group listing can help OCT A to meet commitment that promised in the reform of non-tradable, to better protect the interests of shareholders and listed company, to improve the operational mechanism of OCT group and listed company, to promote the development and construction of large scale project, and finally to achieve the goal of group and listed company.

The model of whole group listing can be divided into three types: the first model is Reverse acquisition model, that means the listed company acquires the assets of group; the second is Merge between listed holding corporations, the premise of this model is that there are two or more listed companies in the group and the parent company has almost no operational business; the last model is group company acquires the listed company and conducts IPO. Compared with the above models, the third model has higher requirements for Group Company including meeting the listing requirements and experiencing long examination and approval procedures.In practice, the first model is more simple and feasible, and Ou Yang \& Tang statistics found that this model accounted for $95 \%$ of whole group listing in China [5].

Reverse acquisition model is a feasible way for OCT to finish the whole group listing in a short time because OCT group has only one domestic listed company. Figure 1 shows the business construction of OCT group before whole group listing.

Through privately issued to group company, OCT A purchased three kinds of assets from 12 companies controlled by Group Company including tourism real estate, hotel and other relevant business. The shares marked on the unlisted companies in the Figure 1 were purchased by OCT A during the reconstruction. OCT group sold all the operational assets to listed company and became Holding Company after the asset reconstruction. The equity ratio hold by OCT group increased from $48.26 \%$ to $56.36 \%$ and the controlling power wasn't changed. OCT group has more clear and integrity business construction after whole group listing, as the holding company, OCT group directly control two listed companies and OCT A have five boards of businesses including theme park, tourism real estate, hotel, paper packing, and other business.

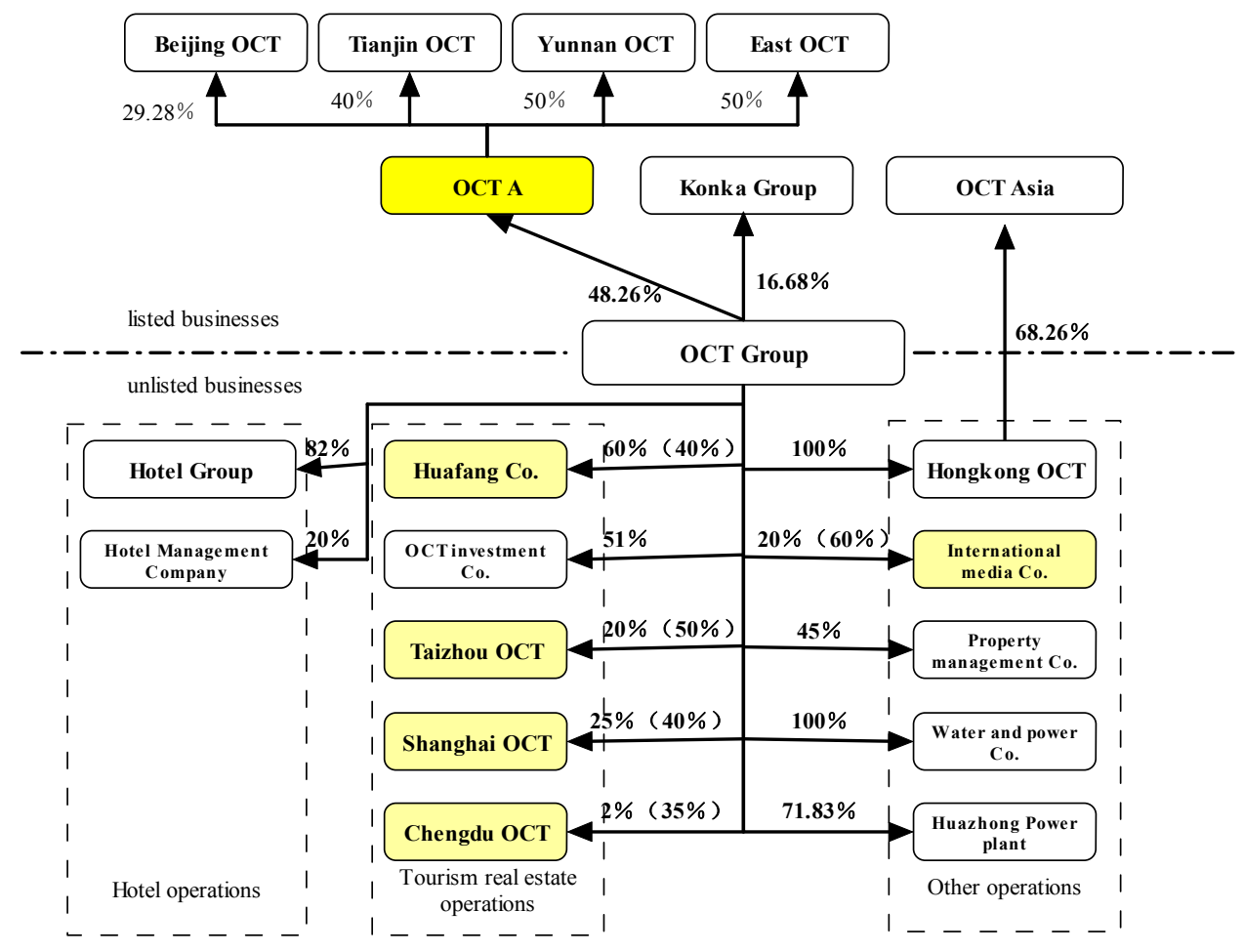

(Notes: The hatched section shows the companies controlled by OCT A before reorganization; the numbers in brackets represent shares owned by OCT A)

Figure 1. Business structures of OCT group before reconstruction. 


\section{The Short-Term Wealth Effect of OCT Group Holistic Listing}

Wealth effect refers to the wealth of financial assets holder increase or decrease as the asset price up or down, in turn to stimulate or suppress consumption [11]. The change of share's wealth is the mirror image of corporate value trend. The price change of stock before and after asset restruction as well as corporate performance change provide sound research basis for wealth effect.

The short-term wealth effect of the paper focuses on the stock price and return fluctuations raised from asset reorganization, while the long-term wealth effect concern the change and trend caused by asset reorganization. The Table 1 shows the process of asset restructing of OCT A.

This paper selected 9 Jun. 2009 as the event day of the whole group listing and the widow period of event were each 20 days before and after event day, together 41 days. The reason for relatively longer window period is that some event information had been leaked before 9 June 2009. Figure 2 shows the changing trend compared between OCT A stock returns and Shenzhen Compound index A returns during the window period, from which we can see that the changing trend of OCT A similar to that of the market, but the amount of variation of OCT A is bigger and returns of OCT A is higher than those of Compound index A.

In order to explore whether the whole group listing brought extra returns for listed company, the paper selected 120 trading days as forecasting period and adopted market model to estimate the abnormal returns of OCT A. The model is following Formula (1).

$$
A R_{t}=R_{t}-\alpha-\beta R_{m}
$$

In the above model, $A R_{t}$, is the abnormal return of firm $i$ in day $t ; R_{t}$ is the reality return in day $t$, the natural logarithm of the ratio of closing price; $\alpha$ and $\beta$ were obtained from regression on return data of estimated days; $R_{m}$ is the market return.

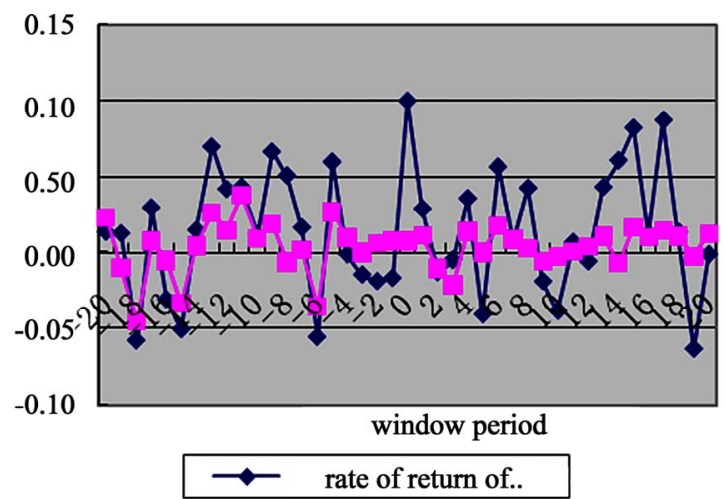

Figure 2. Returns change trend of OCT A during the window period.
Table 1. The process of asset restructing of OCT A.

\begin{tabular}{cl}
\hline Time & \multicolumn{1}{c}{ Event } \\
\hline 19 May 2009 & $\begin{array}{l}\text { Sidecar announcement for significant } \\
\text { asset restricting }\end{array}$ \\
8 June 2009 & $\begin{array}{l}\text { Pass the agreement on issuance of stock } \\
\text { to purchase assets } \\
\text { Official launch announcement and } \\
\text { restore trade } \\
\text { 9 June 2009 }\end{array}$ \\
11 November 2009 & $\begin{array}{l}\text { Private offering shares began trade, } \\
\text { restructing completed }\end{array}$ \\
\hline
\end{tabular}

The regression outcome is following Formula (2):

$$
R_{t}=0.001+0.924 R_{m}
$$

Based on Formula (2), the abnormal returns for some key point are listed on following Table 2.

It can be inferred from the Table 2 that the average abnormal return is $1 \%$ for the event window period $[-20$, $20]$ and pass the T-test of $10 \%$ of the significant level, the abnormal return reach up to $13.4 \%$ during the window period $[-15,15]$ and pass the T-test of $5 \%$ of the significant level. In addition, the paper also calculated the accumulative abnormal returns for each observation period, which all significant in statistic. We can draw a conclusion that the market reacted to the information of whole group listing positively and thus increased the short-term wealth of shareholders.

From the above evidence, we can infer that whole group listing event transferred information to market that quality assets had been invested into listed company and controlling share of major shareholder increased, which have positive significance and market gave positive reflection.

\section{Long-Term Wealth Effects of OCT Group Holistic Listing}

Assets of OCT A increased by $110.49 \%$ since the restruction and the liquidity asset has a sharp rise with increased by $407.85 \%$, at the same time, increase in the proportion of long-term debts and decrease in the proportion of interest-bearing liabilities contribute to the corporate liquidity and lighten the burden of debt repayment. The sound asset structure in turn promotes income structure more reasonable and the tourism real estate mode more outstanding. Table 3 lists the major value creation index.

The financial objective of OCT is to maximize the value of stockholder, from the comparative analysis, we can see that the major value indexes in 2010 are all better than those in 2009. In order to compare OCT A with other companies under the same industry, according to the industry division issued by CSRC (China Securities 
Table 2. Abnormal returns of OCT A.

\begin{tabular}{ccccc}
\hline $\begin{array}{c}\text { Trading } \\
\text { period }\end{array}$ & $\begin{array}{c}\text { Window } \\
\text { period }\end{array}$ & AR & T-value & Sig. (2-tailed) \\
\hline $4.20-7.8$ & {$[-20,20]$} & 0.01 & 1.894 & $0.065^{*}$ \\
$4.27-7.1$ & {$[-15,15]$} & 0.134 & 2.257 & $0.031^{* *}$ \\
${ }^{*} p<0.1 ;{ }^{* *} p<0.05$. & & &
\end{tabular}

Table 3. The major value creation index of OCT A.

\begin{tabular}{lccc}
\hline \multicolumn{1}{c}{ Index } & 2010 & 2009 & 2008 \\
\hline $\begin{array}{l}\text { Sales volume (RMB billion) } \\
\quad \text { Growth rate }\end{array}$ & 17.32 & 10.96 & 8.66 \\
$\begin{array}{l}\text { Income before tax (RMB } \\
\text { billion) }\end{array}$ & 4.35 & 2.38 & 1.96 \\
$\quad$ Growth rate & $(82.8 \%)$ & $(21.43 \%)$ & - \\
$\begin{array}{l}\text { Net profit belongs to } \\
\text { shareholders (RMB billion) }\end{array}$ & 3.04 & 1.71 & 1.43 \\
$\quad$ Growth rate & $(77.8 \%)$ & $(19.6 \%)$ & - \\
$\begin{array}{l}\text { Earnings per share } \\
\text { (RMB/share) }\end{array}$ & 0.98 & 0.55 & 0.46 \\
$\quad$ Growth rate & $(78.2 \%)$ & $(19.6 \%)$ & - \\
$\begin{array}{l}\text { Return on equity } \\
\text { Growth rate }\end{array}$ & $25.71 \%$ & $17.08 \%$ & $16.24 \%$ \\
\hline
\end{tabular}

Regulatory Commission), this paper selected 19 companies as the comparison sample (as shown in Table 4). From the financial data comparison of the tourism industry, we can infer safely that the value creation ability of OCT A is the industry leader. The Table 4 also reflects that the difference between OCT A and industry average has been narrowed year by year, which illustrate that OCT A still need to consolidate and develop the new value growth and give full play advantages of whole group listing.

Table 5 shows the sales sources and composition of OCT A. It can be inferred that the main sources of revenue are tourism and real estate business. With high gross margin, tourism and real estate constitute the core business of value creation. Besides, paper packaging as the new business plate is the new economic growth point fostered by the group. Year 2010 was the first whole business year, from the Table 5, we can see that the proportion of real estate income increased obviously and the high gross margin contributed to form value creation leverage effect. The reason of high gross margin of real estate is that relatively lower land cost for tourism project construction compare to pure city real estate development.

According to the above data and analysis, it can be inferred that OCT A is a capital operating platform for
Table 4. Value creation index comparison under industry.

\begin{tabular}{|c|c|c|c|c|}
\hline Index & & 2010 & 2009 & 2008 \\
\hline \multirow[b]{2}{*}{ Net profit margin } & OCT A & $19.2 \%$ & $17 \%$ & $33.5 \%$ \\
\hline & $\begin{array}{l}\text { Industry } \\
\text { average }\end{array}$ & $14.1 \%$ & $6.3 \%$ & $1.5 \%$ \\
\hline \multirow{2}{*}{$\begin{array}{c}\text { Earnings per share } \\
\text { (RMB/share) }\end{array}$} & OCT A & 0.98 & 0.55 & 0.46 \\
\hline & $\begin{array}{l}\text { Industry } \\
\text { average }\end{array}$ & 0.38 & 0.21 & 0.13 \\
\hline \multirow{2}{*}{ Return on equity } & OCT A & $25.71 \%$ & $17.08 \%$ & $16.24 \%$ \\
\hline & $\begin{array}{l}\text { Industry } \\
\text { average }\end{array}$ & $10.7 \%$ & $7.4 \%$ & $4.8 \%$ \\
\hline
\end{tabular}

Table 5. Sales sources and composition of OCT A after the asset restruction RMB billion.

\begin{tabular}{ccccccc}
\hline & \multicolumn{2}{c}{ Sales } & \multicolumn{2}{c}{ Percentage } & \multicolumn{2}{c}{ Gross margin } \\
\hline & 2009 & 2010 & 2009 & 2010 & 2009 & 2010 \\
\hline $\begin{array}{c}\text { Tourism } \\
\text { comprehensive } \\
\text { income }\end{array}$ & 7.06 & 9.44 & $86.5 \%$ & $54.8 \%$ & $42.36 \%$ & $47.72 \%$ \\
$\begin{array}{c}\text { Real estate } \\
\text { income }\end{array}$ & 3.25 & 7.03 & $29.8 \%$ & $40.8 \%$ & $58.06 \% 59.45 \%$ \\
$\begin{array}{c}\text { Paper packaging } \\
\text { income }\end{array}$ & 0.604 & 0.76 & $5.5 \%$ & $4.4 \%$ & $11.38 \%$ & $12.02 \%$ \\
total & 10.91 & 17.23 & 1 & 1 & $45.82 \% 50.94 \%$ \\
\hline
\end{tabular}

OCT group asset restruction that make the listed company has more clearly business constitute and high ability of value creation. Indisputably speaking, OCT A keep the industry lead.

\section{Conclusions}

\subsection{Holistic Listing Provides Optimized Value Creation Platform}

Holistic listing of OCT Group injects new motivation for value creation and helps shareholders to share in longterm and short-term wealth effects. In the short term, capital market reacted positively to the event of whole group listing and created significant positive abnormal returns. In the long term, ability of value creation for shareholders is relatively high both on basis of horizontal and vertical analysis. The intrinsic reasons for corporate value promotion are as following.

On the one hand, the business boundary of Group Company becomes clear through whole group listing. During the development process of OCT group, formed many subsidiary companies which have business connection but belong to different listed company, thus induced a lot of related transactions and vague the transaction boundary. For example, there are 5 sub-companies of OCT group had connected transaction with OCT A. 
Whole group listing makes these assets become an integral part of whole and contribute to sustainable development of public company.

On the other hand, holistic listing broadens the financing channel for Group Company. OCT A indirectly control OCT Asian Co. via controlling the sub-company Hong Kong OCT, which helps to constructing a sound financing channel on oversea capital market and realize complete control on real estate business in the OCT group, as well as avoid competition between sub-companies belongs to one group.

\subsection{The Path of Promoting Corporate Value through Holistic Listing}

Relying on "tourism + real estate" double drive mode, cultivating paper packaging business as new economic growth point, OCT A has been forming relatively clear value creation path.

The value creation mode of OCT A can be summarized as: based on development of tourism projects and brought theme park brand into full play to realize the maximize margin effects of tourism development. Meantime, the OCT A also mine and cultivate the new value contribution point and form the sustainable value growth.

OCT A also constructed the sound theme park industry chain including tourist attraction, hotel, culture performing and digital entertainment. Real estate is extension and expansion of theme park industry value chain. The proportion of hotel business and real estate business have been raised since the whole group listing, which strength both internal and external industry chain. The replicability feature of business mode of OCT in favor of leverage effect of value creation and increased the value volume through scale effect.

\subsection{Inspiration of Case Study}

This case study has positive reference and enlightenment for other tourism group companies: the source of value creation is perfecting and expanding of industry chain; the major method of value promotion is capital operation.

The value growth of OCT group can be divided into three stages. The first stage was from the company foundation to year 2006, the tourist industry development with the core of theme park construction laid the industry leading position and gradually formed the internal industry chain of tourism. The second stage was from year 2006 to year 2009 before whole group listing, the real estate business increased rapidly and brand effect enhanced obviously in that period, accompanying with tourism industry chain were expanded outwardly and gradually formed the double drive mode of "tourism + real estate" that internal and external linkage. The last stage began from year 2009 after the whole group listing, the assets of OCT group started to be operated in one capital platform, and thus the factors including management structure optimization, broaden financing channel, reduced by affiliated transactions and competition between sub-companies in one group provide shareholders with more reliable value creation sources.

In the framework of Group Company, take tourism business as core and extend to relevant industry, actively participate in capital market, thus finally to promote the value creation ability of Group Company, which may be one solution about the strategy development of Group Company.

\section{Acknowledgements}

Appreciate the following foundation: National Social Science Foundation of China (No. 11CGL026); China Postdoctoral Science Foundation (No. 20090460450); The Education Committee of Beijing (No. PHR201008308); Humanities and Social Sciences Planning Fund Supported by Chinese Ministry of Education (No.10YJA630185).

\section{REFERENCES}

[1] Q. Huang, "Research on Holistic listing of Enterprise Groups," Management World, Vol. 20, No. 2, 2004, pp. 126-130.

[2] G. Jia and W. L. Li, "Information and Ownership Structure Effects of Private Placements as a Payment Method for Purchasing Assets," Journal of Shanxi Finance and Economics University, Vol. 32, No. 10, 2010, pp. 80-87.

[3] X. Z. Guan, “Advantages and Disadvantages of Enterprise Whole Appears on the Market under the Background of Full Circulation," Monthly Magazine, Vol. 28, No. 9, 2009, pp. 52-53.

[4] J. M. Zhang, "Research on Theoretical Basis and Realization Way of Holistic Listing of State-Owned Company," Economic Perspective, Vol. 50, No. 9, 2009, pp. 82-84.

[5] S. Q. Ou Yang and Z. M. Tang, "Research on Holistic Listing and Corporate Performance," Productivity Research, Vol. 25, No. 7, 2010, pp. 215-216.

[6] H. J. Zhu, X. J. He and X. Y. Chen, "Case Study on Tunneling Caused by Private Investment in Public Equity," Management World, Vol. 24, No. 6, 2008, pp. 136-147.

[7] K. H. Wruck, "Equity Ownership Concentration and Firm Value: Evidence from Private Equity Financings," Journal of Financial Economics, Vol. 23, No. 1, 1989, pp. 328. doi:10.1016/0304-405X(89)90003-2

[8] S. Myers and N. Majluf, "Corporate Financing and Investment Decisions When Firms Have Information That Investors Do Not Have?" Journal of Financial Economics, Vol. 13, No. 2, 1984, pp. 187-221.

doi:10.1016/0304-405X(84)90023-0

[9] W. D. Zhang, "The Shor-Run Performance of Private 
Investment in Public Equity and Complete Listing," Accounting Research, Vol. 28, No. 12, 2007, pp. 63-68.

[10] M. Hertzel and R. Smith, "Market Discounts and Shareholder Gains for Placing Equity Privately," Journal of Finance, Vol. 48, No. 2, 1993, pp. 459-485. doi:10.1111/j.1540-6261.1993.tb04723.x

[11] S. M. Li and Y. G. Chen, "Wealth Effects of Merger and Acquisition," Economic Research Journal, Vol. 48, No. 11, 2002, pp. 27-35. 